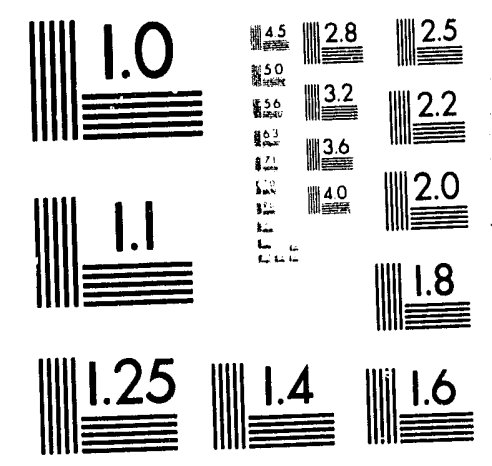



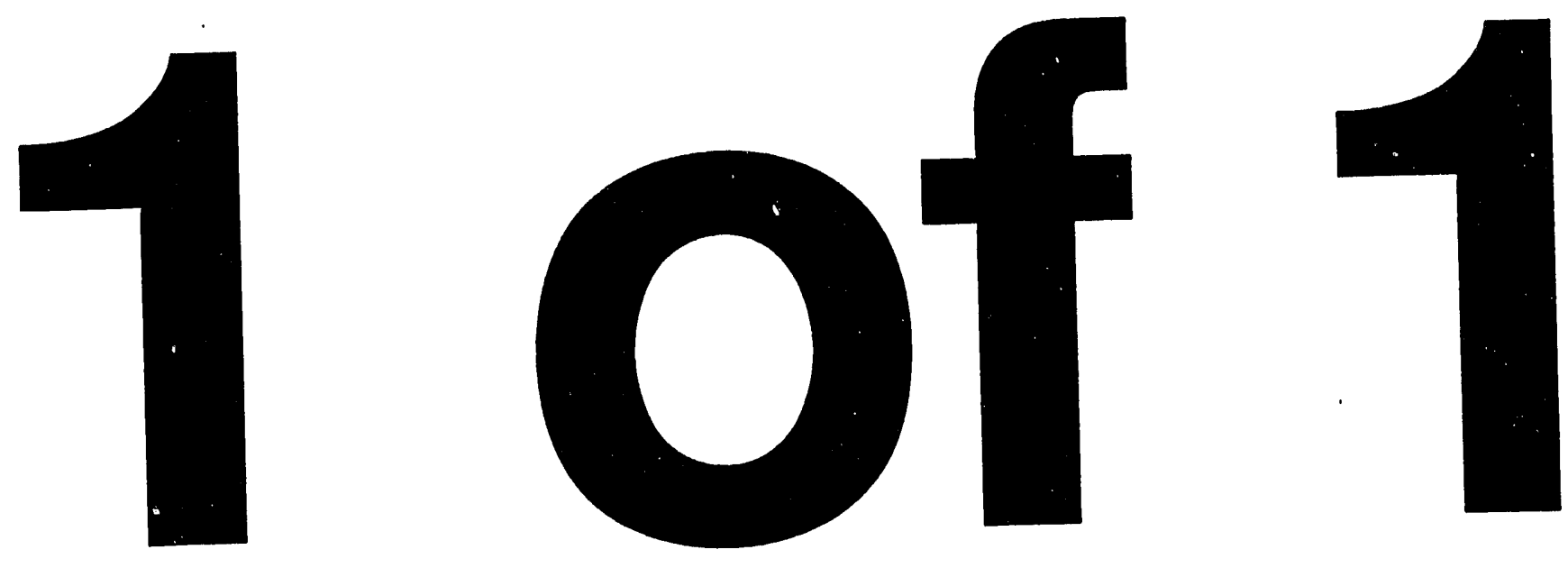


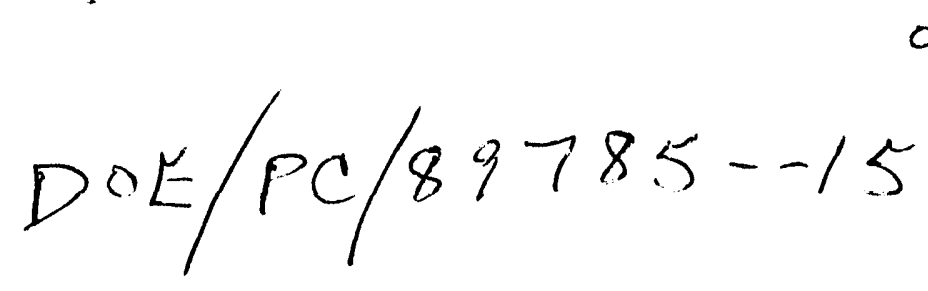

DE-FG22-89PC89785-15

\title{
THE SINGLE ELECTRON CHEMISTRY OF COALS
}

\author{
Report for the period \\ April 1 to June 301993 \\ John W. Larsen \\ and Stephanie E. Rothenberg \\ Department of Chemistry \\ Lehigh University \\ Bethlehem, PA 18015
}

PREPARED FOR THE UNITED STATES DEPARTMENT OF ENERGY

\section{DISCLAIMER}

This report was prepared as an account of work sponsored by an agency of the United States Government. Neither the United States Government nor any agency thereof, nor any of their employees, makes any warranty, express or implied, or assumes any legal liability or responsibility for the accuracy, completeness, or usefulness of any information, apparatus, product, or bility for the accuracy, completeness, or usefulness of any information, apparatus, product, or epresents that its use would not infringe privately owned rights. Reference herein to any specific commercial product, process, or service by trade name, trademark, ence herein to any specific commers not necessarily constitute or imply its endorsement, recommendation, or favoring by the United States Government or any agency thereof. The views and opinions of authors expressed herein do not necessarily state or reflect those of the United States Government or any agency thereof.

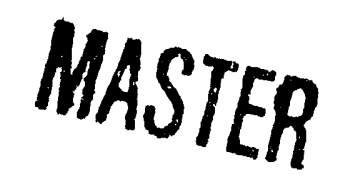

dp

DIST RHBUTION OF THIS DOCUMENT IS INLIMITER 


\section{OBJECTIVES AND SCOPE OF WORK}

objectives

To investigate and characterize the single electron reactions of alkyl and alkoxy aromatic compounds in order to determine the role these reactions play in the chemistry of coal.

\section{Scope of Work}

1. Attempts will be made to demonstrate that the radicals from inertinite maceral group will initiate the polymerization of 4-vinylpyridine.

2. The molecule, $\mathrm{N}, \mathrm{N}$-diphenyl-phenylenediamine, will be deposited in coals to characterize their native free radicals.

3. Tetracyanoquinodimethane (TCNQ) and tetracyanoethylene (TCNE) will be used to characterize the numbers and strengths of single electron donors in coals. 


\section{Introduction}

Tetracyanoethylene (TCNE) and Tetracyanoquinodimethane (TCNQ) were used earlier in an attempt to determine the single electron donating ability of aromatic groups in coals.1,2 The extent of electron transfer from coals to these compounds was measured by determining the frequency shift of the nitrile stretching bands in the Diffuse Reflectance (DR) infrared spectra. ${ }^{3}$

Our addition to this work will be to study the interactions of coals, such as Illinois No. 6, with TCNE. We will determine whether a Diels-Alder reaction or other addition reactions are occurring.

\section{Experimental}

\section{Materials}

HPLC grade pyridine (Aldrich) was dried over potassium hydroxide overnight and purged with dry nitrogen before sealing with a septum. Illinois No. 6 coal from the Argonne premium coal bank was dried in a vacuum oven at $110^{\circ} \mathrm{C}$ for 24 hours and transferred to a $\mathrm{N}_{2}$-filled drybox. Potassium bromide (KBr) (Fischer) was dried at $450^{\circ} \mathrm{C}$ in vacuum for two days, sealed and transferred to the drybox. Tetracyanoethylene (TCNE) was transferred to the drybox and used as received.

\section{Deposition of TCNE on Argonne Premium Illinois No. 6 coal}

In a Vacuum Atmosphere drybox, $1.30 \mathrm{~g}$ of TCNE was weighed into a preweighed $250 \mathrm{ml}$ flask and sealed with a septum. Illinois No. 
6 coal (128 $\mathrm{mg}$ ) was added to a preweighed test tube. A magnetic stirrer was added to the tube and sealed with a septum. The test tube and flask were removed from the drybox to a hood. With a syringe, $50 \mathrm{ml}$ of pyridine was added to the TCNE to make a $0.16 \mathrm{M}$ stock solution. The solution was stirred until all the TCNE was dissolved. With a syringe, $5 \mathrm{ml}$ of stock solution was added to the coal. For 24 hours, the mixture was stirred under $\mathrm{N}_{2}$. The sample was then dried in the vacuum at room temperature until it reached constant weight.

\section{Preparation of Physical Mixture for IR analysis}

Sample preparation ${ }^{4}$ was carried out in a $\mathrm{N}_{2}$-filled drybox. It entailed pregrinding $300 \mathrm{mg}$ of TCNE-IIlinois No. 6 coal complex and $\mathrm{KBr}$ in a Wig-L-Bug for 3 minutes. The complex $(0.023 \mathrm{~g})$ and $\mathrm{KBr}$ $(0.743 \mathrm{~g})$ were coground for an additional 3 minutes making a $3.0 \%$ mixture. The sample was transferred to the Harrick cell and leveled with a spatula. The cell was removed from the drybox, placed in the Mattson FT-IR, and appropriate spectra were recorded.

\section{IR Analysis and Methods}

Diffuse Reflectance infrared analysis was performed using a Mattson Fourier transform infrared spectrometer in conjunction with a 2-Dimensional Harrick Scientific Praying Mantis Diffuse Reflectance Attachment (DRA). The software used was Enhanced FIRST by Mattson Instrument Inc. The Harrick cell thermocouples were attached to a Model 49 Proportioning Controller from Love Control Corporation. During IR analysis, the TCNE-IIlinois No. 6 coal 
reaction mixture was heated from room temperature to $180^{\circ} \mathrm{C}$ within the Harrick cell for 7.5 hours. All spectra were obtained using 1000 scans at $4 \mathrm{~cm}^{-1}$ resolution.

\section{Results and Discussion}

In our last report, ${ }^{5}$ we demonstrated that the DR spectrum of the charge transfer complex, TCNE-Illinois No. 6 ccal, at room temperature does not show evidence for any chemical reaction between the coal and TCNE. At the present, it is established that there has been $69 \%$ electron density transfer from Illinois No. 6 coal to the TCNE's lowest unoccupied molecular orbital (LUMO) 3,6 calculated from the shift in the $\mathrm{CN}$ stretching frequency in the spectrum shown in Figure 1 . Since no chemical reaction was observed, we continue this study by heating the complex from room temperature to $180^{\circ} \mathrm{C}$ during IR analysis to see if Diels-Alder or other addition reactions occurred.

While heating the complex for 7.5 hours from room temperature to $180^{\circ} \mathrm{C}$, the $\mathrm{DR}$ spectrum of the complex displayed no change in the extent of charge transfer as shown in Figure 2: The position of the nitrile band did not shift. Because of this result, a Diels-Alder reaction or other addition reactions are not possible in Illinois No. 6 coal even at higher temperatures and despite the fact that TCNE is an excellent dienophile. 7

The occurrence of a Diels-Alder reaction would produce $\mathrm{CN}$ groups which are not conjugated to a double bond. These nonconjugated $C N$ groups have stretching frequencies between $2260 \mathrm{~cm}^{-1}$ and $2240 \mathrm{~cm}^{-1} \cdot 8,9$ There are no bands in this region of the IR 
spectrum found; therefore, an addition reaction has not occurred nor has any reaction which produces a non-conjugated $\mathrm{CN}$.

The data obtained confirms that the TCNE's LUMO was still occupied $2 / 3$ of an electron transferred by Illinois No. 6 coal. A Diels-Alder reaction of the TCNE radical anion is forbidden by the Woodward-Hoffman rules. It is reasonable that the presence of a transferred electron density in the LUMO is sufficient to block occurrence of this reaction. The data is consistent with the existence of extended $\pi$ structures in Illinois No. 6 coal; an electron transition occurs within the IR frequency range. 10

Further analysis will be carried out. The sample will be stirred for 1 week instead of 1 day and the complex will be examined by DR infrared analysis after 24 hours at $250^{\circ} \mathrm{C}$. 


\section{References}

1. Larsen, J. W., Flowers, R. A., "The Single Electron Chemistry of Coals, A paper prepared or the Department of Energy", \#DE-FG22-89PC89785-1

2. Larsen, J. W., Flowers, R. A., "The Single Electron Chemistry of Coals, A paper prepared for the Department of Energy", \#DE-FG22-89PC89785-3

3. Flowers, R. A. PhD. dissertation. Lehigh University, 1991.

4. Larsen, J. W., Baskar, A. J., Energy and Fuel, 1987, 1, 230.

5. Larsen, J. W., Rothenberg, S. E., "The Single Electron Chemistry of Coals, A paper prepared for the Department of Energy", \#DEFG22-89PC89785-14

E. Chappell, J. S., Bloch, A. N., Bryden, W. A., Maxfield, M., Poehler, T. O., Cowan, D. O., J. Am. Chem. SoC., 1981, 103, 2442 .

7. Sauer, J., Wuest, H., Mielert, A., Chem. Ber., 1964, 97, 3183.

8. Bellamy, L. J., "The Infra-red Spectra of Complex Molecules", Wiley, New York, 1964, p.263-276.

9. Kitson, R. E., Griffith, N. E., Analytical Chem., 1952, 24, 334 .

10. Larsen, J. W. , Flowers II, R. A., Hall, F., Silbernagel, B. G, Gebhard, L. A., Int. Coal Conf. Sem., 1991, 1. 


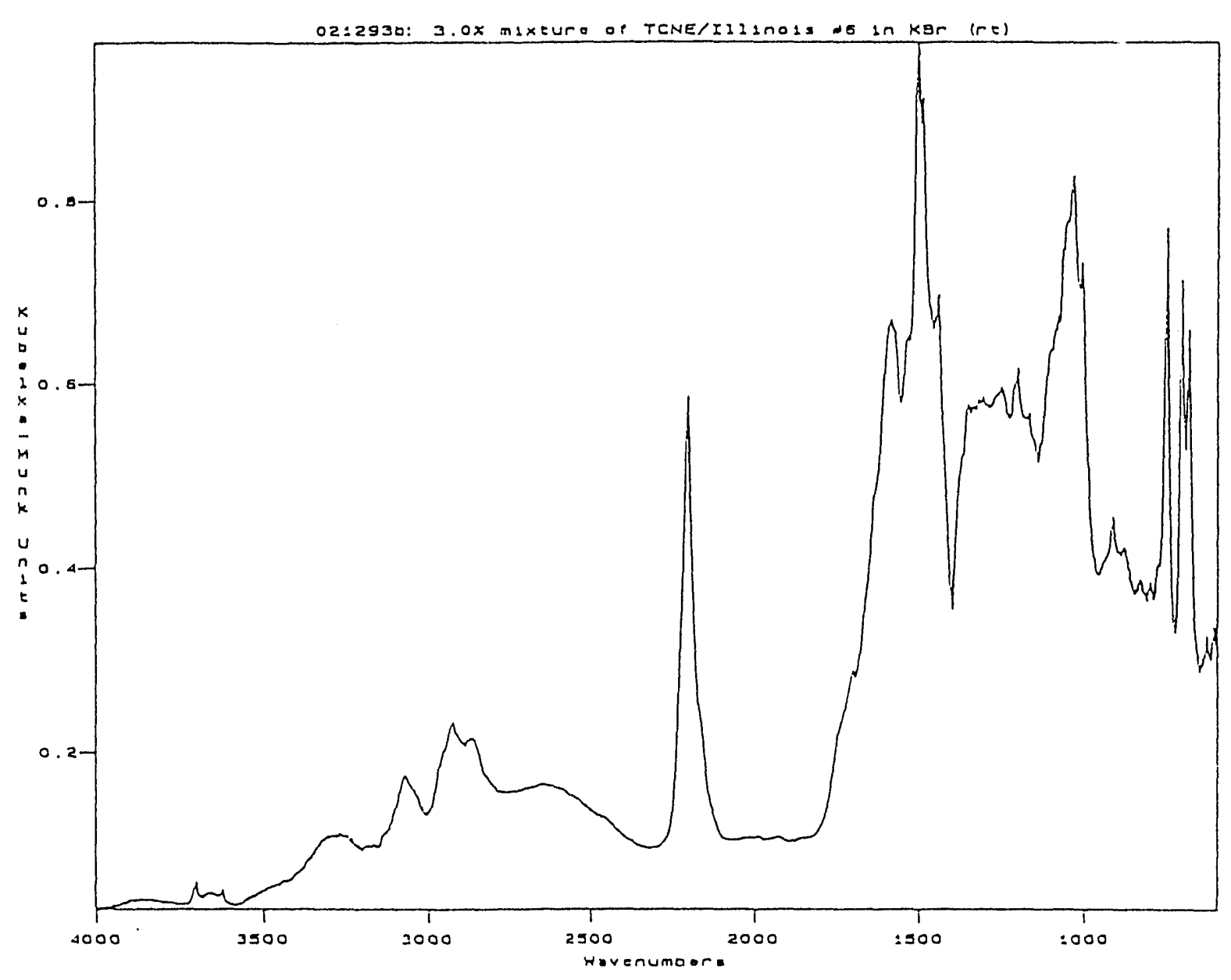

Figure 1: DR spectrum of TCNE-IIlinois No. 6 coal reaction mixture at room temperature 


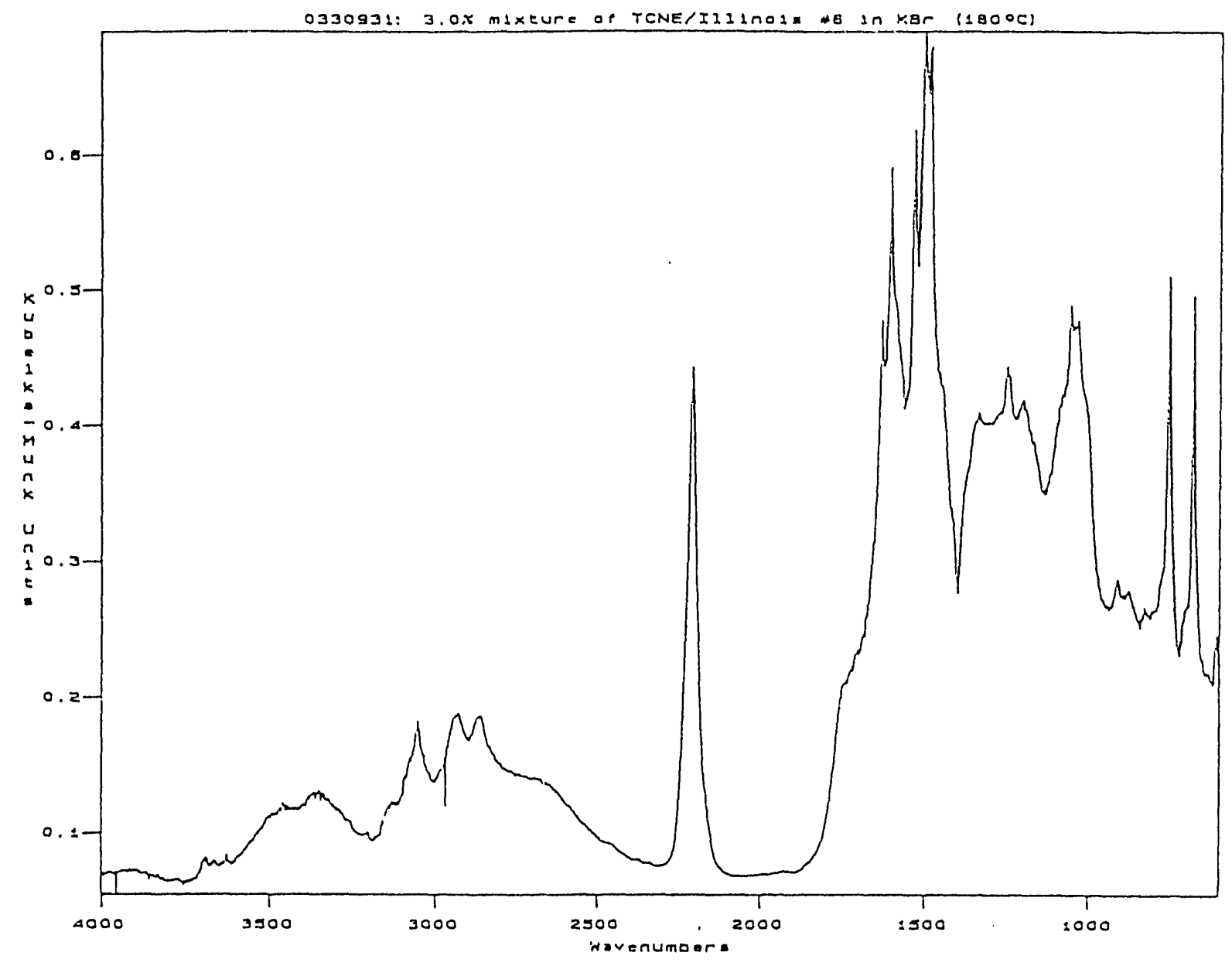

Figure 2: DR spectrum of TCNE-Illinois No. 6 coal reaction mixture at $180^{\circ} \mathrm{C}$. 


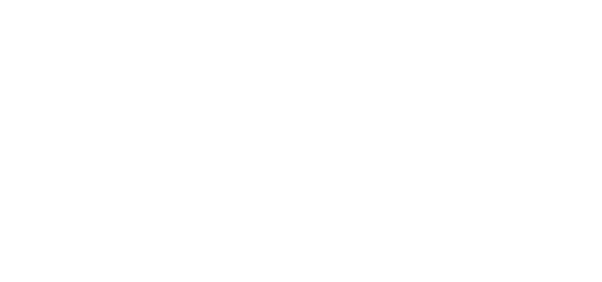